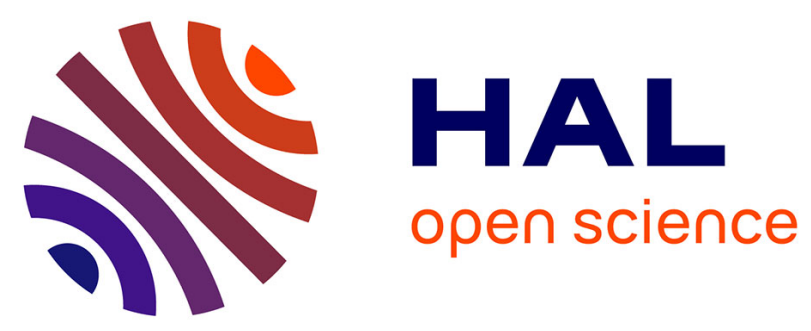

\title{
The GHYRAF (Gravity and Hydrology in Africa) experiment: Description and first results
}

J. Hinderer, C. de Linage, J.-P. Boy, P. Gegout, F. Masson, Y. Rogister, M. Amalvict, J. Pfeffer, F. Littel, B. Luck, et al.

\section{- To cite this version:}

J. Hinderer, C. de Linage, J.-P. Boy, P. Gegout, F. Masson, et al.. The GHYRAF (Gravity and Hydrology in Africa) experiment: Description and first results. Journal of Geodynamics, 2009, 48 (3-5), pp.172-181. 10.1016/j.jog.2009.09.014 . hal-02884064

\section{HAL Id: hal-02884064 \\ https://hal.umontpellier.fr/hal-02884064}

Submitted on 29 Jun 2020

HAL is a multi-disciplinary open access archive for the deposit and dissemination of scientific research documents, whether they are published or not. The documents may come from teaching and research institutions in France or abroad, or from public or private research centers.
L'archive ouverte pluridisciplinaire HAL, est destinée au dépôt et à la diffusion de documents scientifiques de niveau recherche, publiés ou non, émanant des établissements d'enseignement et de recherche français ou étrangers, des laboratoires publics ou privés. 


\title{
The GHYRAF (Gravity and Hydrology in Africa) experiment: Description and first results
}

\author{
J. Hinderer ${ }^{a, *}$, C. de Linage ${ }^{a, i}$, J.-P. Boy ${ }^{a, j}$, P. Gegout ${ }^{a}$, F. Masson ${ }^{a}$, Y. Rogister a , M. Amalvict ${ }^{a}$, J. Pfeffer ${ }^{a}$, \\ F. Littel ${ }^{a}$, B. Luck $^{a}$, R. Bayer ${ }^{b}$, C. Champollion ${ }^{b}$, P. Collard ${ }^{b}$, N. Le Moigne ${ }^{b}$, M. Diament ${ }^{c}$, S. Deroussi ${ }^{c}$, \\ O. de Viron ${ }^{c}$, R. Biancale ${ }^{d}$, J.-M. Lemoine ${ }^{d}$, S. Bonvalot ${ }^{e}$, G. Gabalda ${ }^{e}$, O. Bock ${ }^{f}$, P. Genthon ${ }^{g}$, \\ M. Boucher ${ }^{g}$, G. Favreau ${ }^{g}$, L. Séguis ${ }^{g}$, F. Delclaux ${ }^{g}$, B. Cappelaere ${ }^{g}$, M. Oi $^{g}$, M. Descloitres ${ }^{h}$, \\ S. Galle ${ }^{h}$, J.-P. Laurent ${ }^{h}$, A. Legchenko ${ }^{h}$, M.-N. Bouin ${ }^{k}$
}

a Institut de Physique du Globe de Strasbourg (UMR 7516 CNRS/Université de Strasbourg), 67084 Strasbourg, France

${ }^{b}$ Géosciences Montpellier (UMR 5243 CNRS/Université Montpellier 2), 34095 Montpellier, France

${ }^{c}$ Institut de Physique du Globe de Paris (UMR 7154 CNRS/IPGP/Université Paris 7), 75252 Paris, France

d Dynamique terrestre et planétaire (UMR 5562 CNRS/Université Paul Sabatier), 31400 Toulouse, France

e Laboratoire des Mécanismes et Transferts en Géologie (UMR 5563 CNRS/IRD/Université Paul Sabatier), 31400 Toulouse, France

${ }^{f}$ Laboratoire de Recherche en Géodésie/IGN, 77455 Marne la Vallée, France

g Hydrosciences Montpellier (UMR 5569 CNRS/IRD/Université Montpellier 2), 34095 Montpellier, France

h Laboratoire d'étude des Transferts en Hydrologie et Environnement (UMR 5564 CNRS/INPG/IRD/Université Joseph Fourier), 38041 Grenoble, France

i University of California, Irvine, Department of Earth System Science, Croul Hall, Irvine, CA 92697-3100, USA

j NASA GSFC Planetary Geodynamics Laboratory, Greenbelt, MD 20771, USA

${ }^{k}$ CNRM/Centre de Météorologie Marine, 29604 Brest, France

\section{arti cle info}

\section{Keywords:}

Gravity

GPS

Water storage

Sahel

Monsoon

\begin{abstract}
a bstract
This paper is the first presentation of a project called GHYRAF (Gravity and Hydrology in Africa) devoted to the detailed comparison between models and multidisciplinary observations (ground and satellite gravity, geodesy, hydrology, meteorology) of the variations of water storage in Africa from the Sahara arid part to the monsoon equatorial part. We describe the various actions planned in this project. first detail the actions planned in gravimetry which consist in two main surface gravity experiments: on the one hand the periodic repetition of absolute gravity measurements along a north-south monsoonal gradient of rainfall in West Africa, going from Tamanrasset $(20 \mathrm{~mm} / \mathrm{year})$ in southern Algeria to Djougou (1200 mm/year) in central Benin; on the other hand the continuous measurements at Djougou (Benin) with a superconducting gravimeter to monitor with a higher sampling rate the gravity changes related to an extreme hydrological cycle. Another section describes the actions planned in GPS which will maintain and develop the present-day existing network in West Africa. The third type of actions deals with hydrology and we review the three sites that will be investigated in this joint hydrogeophysics project namely Wankama (near Niamey) and Bagara (near Diffa) in the Niger Sahelian zone and Nalohou (near Djougou) in the Benin monsoon zone. We also address the question of the ground truth of satellite-derived missions; in this context the GHYRAF project will lead to test the hydrology models by comparison both with in situ and satellite data such as GRACE, as well as to an important increase of our knowledge of the seasonal water cycle in Africa. We finally present preliminary results in GPS based on the analysis of the vertical motion of the Djougou site. The resulting absolute gravity changes related to the 2008 monsoon are finally given.
\end{abstract}

\section{Introduction}

GHYRAF (Gravity and Hydrology in Africa) is a multidisciplinary project that aims to better understand the water cycle in

\footnotetext{
* Corresponding author.

E-mail address: jacques.hinderer@eost.u-strasbg.fr (J. Hinderer).
}

West Africa from a combination of geodetic (GPS), gravity (surface and satellite-derived), hydrogeophysics (Magnetic Resonance Sounding and resistivity methods) and hydrology experiments. We will focus on four specific sites with very different hydrological conditions: the first one is located in the Sahara desert zone (Tamanrasset, Algeria); two of them sample the Sahelian band (Niamey and Diffa in Niger) and the last one the monsoon zone (Djougou, Benin). Djougou is the location of an 
existing hydrometeorological environmental Observatory of the AMMA (African Multidisciplinary Monsoon Analysis) program (http://amma.mediasfrance.org/) with a very dense network of hydrological, geophysical and meteorological data. This is why we plan to install there a superconducting gravimeter in order to monitor the time-variable surface gravity resulting from changes in water storage in a region submitted to heavy precipitations during the monsoon.

The teams involved in this federating project, namely IPGS (Strasbourg), Géosciences (Montpellier), IPGP (Paris), DTP/CNES (Toulouse), LMTG/IRD (Toulouse), have developed complementary expertises in fieldwork, ground and space data processing and geophysical interpretation. The multidisciplinary aspect the project will benefit to the whole gravimetry community. LAREG/IGN (Marne la Vallée) is also partner of the project since we need to combine gravity data with precise positioning (GPS) at every measurement point; this will be done using permanent GPS receivers managed in West Africa by the AMMA geodesists and establishing new sites when needed (e.g. in Diffa, Niger).

The participation of hydrologists from IRD/Hydrosciences (Montpellier) and IRD/LTHE (Grenoble) further strengthens the multidisciplinary approach of the project. Their expertise in field measurements and hydrology modelling, as well as the numerous hydrological data they will provide in several sites, will be essential.

Climate changes impact water resources and a better knowledge of the present-day variations in water storage worldwide, and more specifically in the tropical monsoon zones where the variability is large, is needed as stressed by a recent IPCC report (Bates et al., 2008). A primary goal of the proposal is to set up new constraints to the problem of the monsoon cycle in Africa since our ground measurements as well as satellite ones are sensitive to the total variation of stored water (changes in the total water column i.e. surface water, water of the unsaturated zone and groundwater), which is an additional independent information on the internal state of an hydrosystem. The Niamey site is interesting because there is an apparent long-term increase in water storage despite a deficit in rainfall (Favreau et al., 2009) while our study in the Diffa region will allow to investigate the impact of the shrinkage of lake Chad in terms of water resources. The Benin site shows widespread pluri-metric water table seasonal fluctuations.

A useful by-product will be the ground validation of time-variable solutions of the Earth's gravity field derived from satellite mission GRACE (Gravity Recovery and Climate Experiment) launched in 2002. As for any new type of measurement, it is necessary to test the quality of these gravity solutions with respect to independent data. Presently the satellite data are often compared to predictions of global models for the atmosphere, oceans and hydrology, whereas they are supposed to be used as constraints to improve these models. Therefore we propose to collect a set of new, independent and high quality ground data to test the quality of the satellite observations and to investigate how information from space and ground gravity can be combined and optimally used to assess and improve the quality of the hydrology models. Comparing GRACE and ground surface observations needs to understand in detail the local hydrological system at various sites. This will be done at our selected sites by a multidisciplinary approach including geophysical and hydrogeological observations. These sites have been chosen because they are representative of hydrological processes studied for a long time and hence will allow an efficient comparison of local water storage changes with larger scale models.

Finally, let us mention that this ambitious multidisciplinary project requires the most accurate ground instruments (FG5 absolute gravimeter and GWR superconducting gravimeter) with strong needs in terms of manpower and logistics. Our project has been designed to provide scientific outcome for the knowledge of the

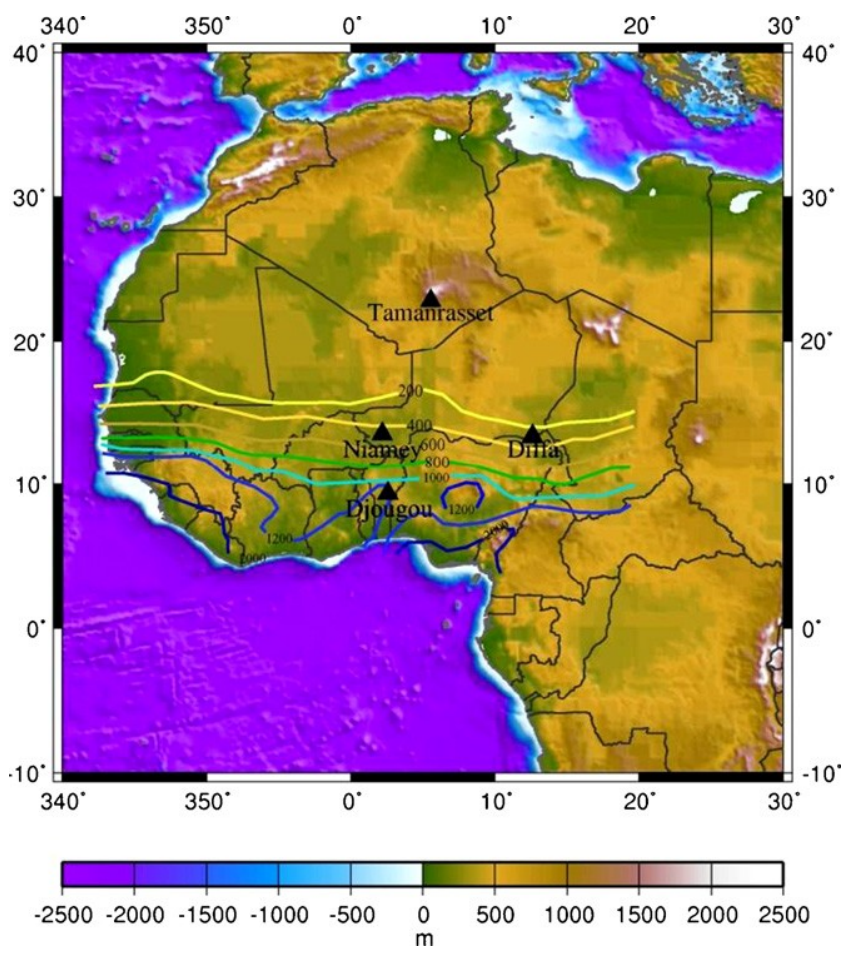

Fig. 1. Location of the study sites in western Africa along the monsoonal rainfall latitudinal gradient (in mm/year, period 1950-1989). For Tamanrasset, the value is very low (less than $20 \mathrm{~mm} /$ year)

water cycle in Africa as well as for the confrontation of ground measurements with those from space gravity missions.

\section{Description of the GHYRAF project}

\subsection{Actions planned in gravimetry}

We propose in this project to set up two original gravity experiments:

- On the one hand, the repetition of absolute gravity measurements carried out four times per year on a profile sampling both the Sahara desert zone and the humid monsoon zone of equatorial Africa with FG5 absolute gravimeters (+ complementary A10 and Scintrex measurements).

- On the other hand, a continuous monitoring with a GWR superconducting gravimeter at the Djougou (Benin) site where large gravity signals are expected from the hydrology models.

The profile goes from the arid Sahara region (Tamanrasset, Algeria) to a low latitude zone in Africa (Djougou, Benin) where a strong monsoon signal can be observed (see Fig. 1; Table 1); the colored lines show the isohyet distribution (in mm/year) after L'Hote et Mahé (1996) and point out the strong north-south gradient of rainfall in this region. Other planned sites are Diffa (Niger) close to

Table 1

Location of the stations of absolute gravity profile and mean annual rainfall (in $\mathrm{mm} /$ year)

\begin{tabular}{lllllc}
\hline Location & Country & Longitude & Latitude & Code & Rainfall $(\mathrm{mm} / \mathrm{year})$ \\
\hline Tamanrasset & Algeria & $5.52 \mathrm{E}$ & $22.78 \mathrm{~N}$ & TAM & 20 \\
Diffa & Niger & $12.62 \mathrm{E}$ & $13.32 \mathrm{~N}$ & DIFF & 300 \\
Niamey & Niger & $2.17 \mathrm{E}$ & $13.48 \mathrm{~N}$ & NIAM & 560 \\
Djougou & Benin & $2.62 \mathrm{E}$ & $9.35 \mathrm{~N}$ & DJOU & 1200 \\
\hline
\end{tabular}



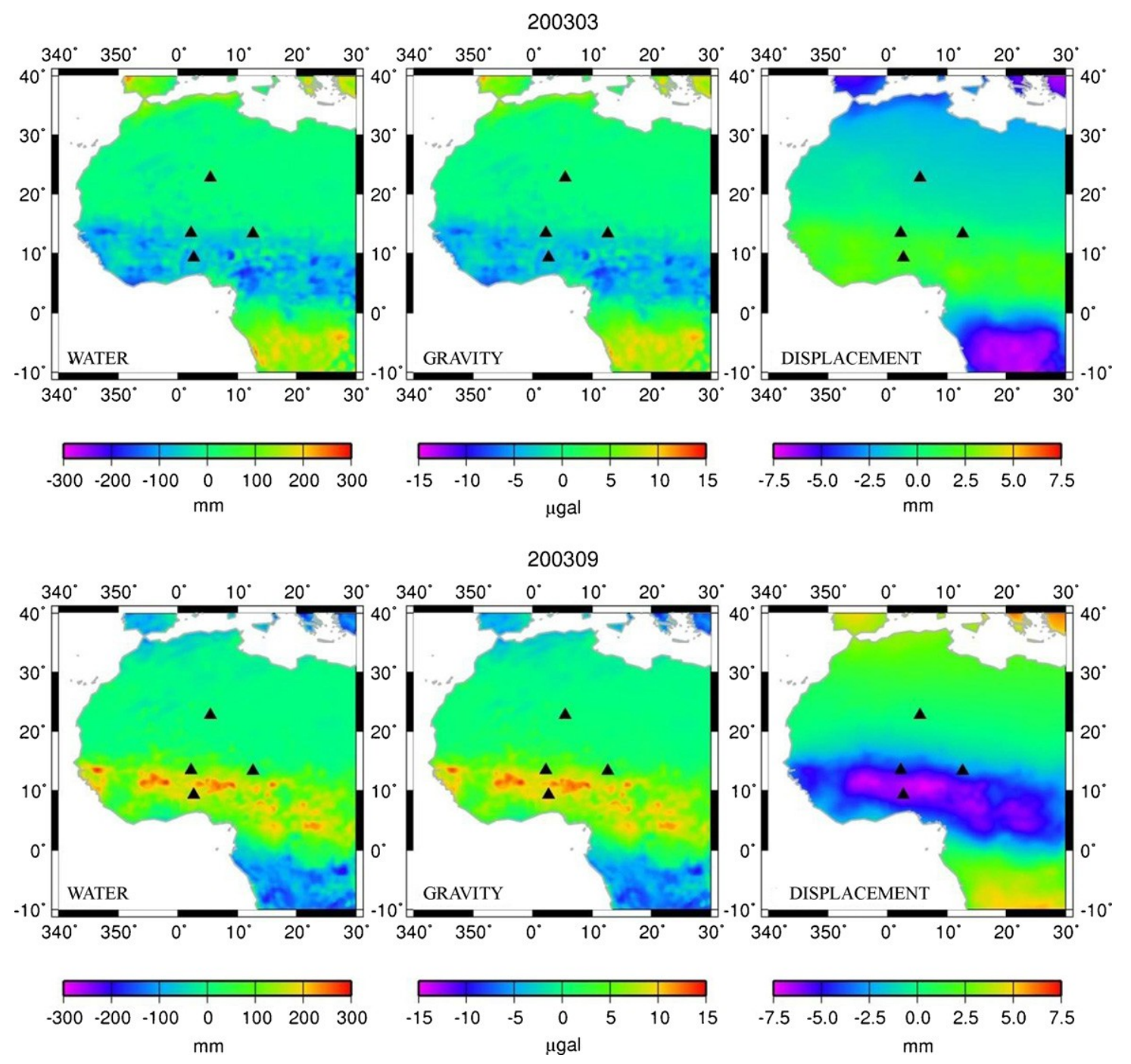

Fig. 2. Hydrological load (in mm of water equivalent) from the GLDAS model (left) and induced gravity changes (in $\square$ Gal) (center) and ground vertical displacement (in mm) (right) for March and September 2003. By convention, vertical displacement is positive upwards and gravity change is positive downwards.

Lake Chad and Niamey (Niger). Niamey and Djougou are located in the investigation zone of the AMMA program where an important international effort is made to better understand the African monsoon (Lebel et al., 2003a,b; Redelsperger et al., 2006).

How did we select these stations? The first answer is given in Fig. 2 that shows the gravity and height changes from the outputs of GLDAS hydrological model (Rodell et al., 2004) for March and September 2003. We represent the hydrological load (the soil moisture component in $\mathrm{mm}$ of equivalent water), the predicted gravity changes in $\square \mathrm{Gal}\left(1 \square \mathrm{Gal}=10^{-8} \mathrm{~m} \mathrm{~s}^{-2}\right)$ and vertical displacement of the ground in $\mathrm{mm}$. The seasonal changes may reach amplitudes as large as $15 \square \mathrm{Gal}$ in gravity and $10 \mathrm{~mm}$ in displacement, which are much larger than the precision of gravity and GPS observations.

An example of unexplained gravity differences (in $\mathrm{m} \mathrm{s}^{-2}$ ) between models and GRACE observations is given in Fig. 3 for the months of March and September 2003. The upper left part shows the gravity changes induced by the raw hydrological LadWorld of Milly and Shmakin (2002) for our zone of interest; this corresponds in fact to a maximum harmonic degree $n=180$ since the model is available on a $1^{\circ} \times 1^{\circ}$ grid. The upper right part is the gravity when the model is truncated at degree $n=15$ i.e. a spatial resolution of about $1300 \mathrm{~km}$. Finally the central lower part depicts the GRACE solutions truncated at the same degree. If the patterns between model and observations are similar for a given truncation, one can notice that the anomalies of the equatorial band (in blue for March and red for September) are slightly stronger in the GRACE data than the ones predicted by LadWorld.

Moreover, although the raw LadWorld model predicts almost no hydrologically induced gravity change due to soil moisture variations in Tamanrasset, GRACE observations indicate a non-negligible change, especially in March 2003. In fact, if the soil moisture models are correct, the difference between observations and models may then be attributed to deeper ground water changes.

The first point of our profile is Tamanrasset (Algeria) in the arid Sahara region where an Observatory with a permanent GPS belongs to CRAAG (Centre de Recherche en Astronomie, Astrophysique et Géophysique, Alger). This site is also interesting since there is an AG measurement that was done there some years ago (O. Francis, personal communication). We will have two measurement sites in Niger: Diffa, close to Lake Chad and Niamey which are both in the Sahelian zone and, therefore, intermediary between the arid point in the North and the monsoon point in the South. The choice of Tamanrasset with almost no hydrological change is justified because this location will allow to perform the 'null test' (i.e. to measure at a place where only a very small amplitude of the seasonal gravity change is predicted). Two other stations are in the AMMA investigation zone 
$\begin{array}{rrrr}-2 \mathrm{e}-007 \cdot 1 \mathrm{e} \cdot 007 & 0 & 1 \mathrm{e} \cdot 007 \quad 2 \mathrm{e}-007\end{array}$

gravity variations in $\mathrm{m} / \mathrm{s} 2$ predicted by LaDWorld (full resolution)
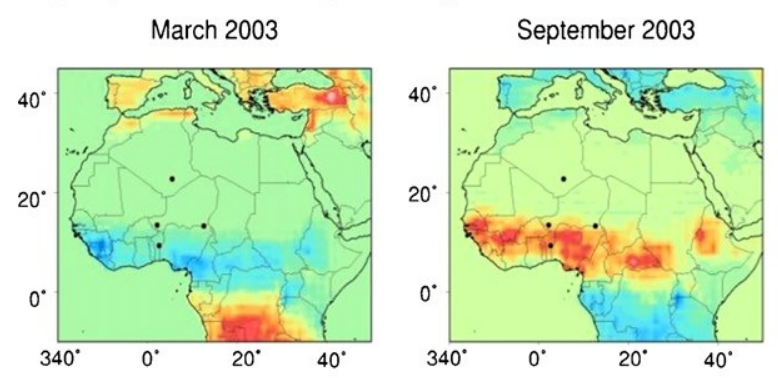

$\begin{array}{rrrr}-2 \mathrm{e}-007-1 \mathrm{e}-007 & 0 & 1 \mathrm{e}-007 & 2 \mathrm{e}-007\end{array}$

gravity variations in $\mathrm{m} / \mathrm{s} 2$ predicted by LaDWorld (truncation at degree 15)
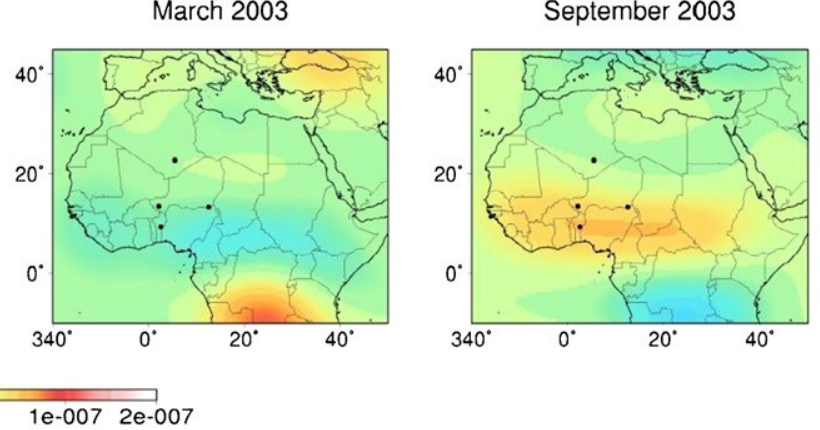

$-2 \mathrm{e}-007-1 \mathrm{e}-007 \quad 0 \quad 1 \mathrm{e}-007 \quad 2 \mathrm{e}-007$

GRACE gravity variations in $\mathrm{m} / \mathrm{s} 2$ (truncation at degree 15)
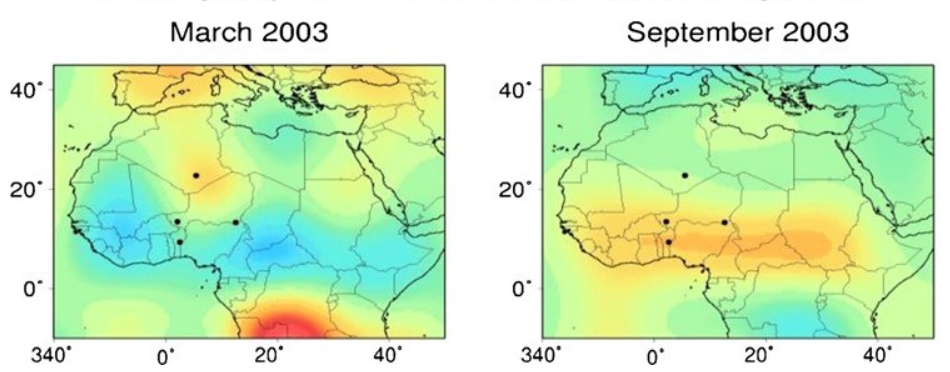

Fig. 3. Differences for March and September 2003 of the gravity field (in $\mathrm{m} \mathrm{s}$ corresponding to a interpretation of the references to color in this figure legend, the reader is referred to the web version of the article.)

and some of them are already equipped with permanent receivers

The gravity changes (in $\square \mathrm{Gal}$ ) and vertical displacement (in $\mathrm{mm}$ ) due to the soil moisture content (GLDAS model) for the time span 2002-2006 are computed for the stations of Table 1 and shown on Fig. 4 respectively in red and blue. One notices that, as expected, there is almost no gravity change in Tamanrasset (less than $1 \square \mathrm{Gal}$ ) and that, on the contrary, gravity varies strongly (more $15 \square \mathrm{Gal}$ peak to peak) in Djougou.

To detect the monsoon hydrological signal we need instruments that are both precise and stable. Consequently, we propose to make all our regular gravity measurements along the profiles with FG5 ballistic absolute gravimeters (Micro-g Solutions Inc.) which have the required accuracy ( $2 \square \mathrm{Gal}$ ) and which are time invariant (Niebauer et al., 1995). An example of using FG5 measurements to investigate hydrology problems was recently shown for a karstic aquifer in the Larzac plateau (France) by Jacob et al. (2008) with signal amplitudes reaching $15 \square \mathrm{Gal}$ and measurement accuracy slightly better than $2 \square$ Gal.

In addition to the absolute gravity campaigns, we plan to install a permanent gravity station at Djougou equipped with a field superconducting gravimeter (FSG) manufactured by GWR Instruments (http://www.gwrinstruments.com) to have a continuous monitoring of time-variable gravity. The reasons are that superconducting gravimeters are more precise, by at least a factor 10 , than FG5 absolute gravimeters; they allow a dense time sampling (1 s) and the investigation of gravity signals on a wide spectrum (Hinderer and Crossley, 2000, 2004). A recent study has shown that SGs are, indeed, capable of retrieving the annual hydrological signal in gravity at the various stations (Boy and Hinderer, 2006; Van Camp et al., 2006) operating in the framework of the GGP international project (Crossley et al., 1999) and discrepancies in amplitude are often found to be related to topographical attraction effects of nearby water masses in the case of underground stations.
The very low drift AG measurements and its high sensitivity will tor the annual cycle and transient sub-annual changes known to be present in this region with high precipitation variability.

In addition to the repetition of FG5 measurements, we also plan to set up twice per year complementary measurements on the profile with an A10 absolute gravimeter. These field measurements, which are easier, though less precise, to perform than with the FG5, will have two objectives:

- Repeating measurements of horizontal gradients in a distance range $(10 \mathrm{~m}$ to $10 \mathrm{~km})$ around the FG5 points in order to detect any temporal variation which may arise from local effects.

- Allowing denser absolute measurements on specific segments of the profiles according to the first results and predictions from the hydrology models.

Finally, we will also use SCINTREX micro-gravimeters (CG5-M) to measure the vertical gradients at every site of the profiles, and to perform gravity links between our AG points and hydro-geodetic benchmarks. Furthermore, densifying the gravity observations around the FG5 stations at Djougou and Niamey will help to refine the local hydrological models as demonstrated by the studies of Pool and Eychaner (1995), Naujoks et al. (2008) and Gehman et al. (2009)

\subsection{Actions planned in GPS}

Compared to the gravity changes observed by satellites, ground gravity is, in addition, sensitive to the vertical motion of the station (free air effect). The comparison of the two types of information requires that the surface measurements are corrected for this contribution. This is why we propose to use permanent GPS receivers of geodetic quality on all the gravity sites. Several of our 

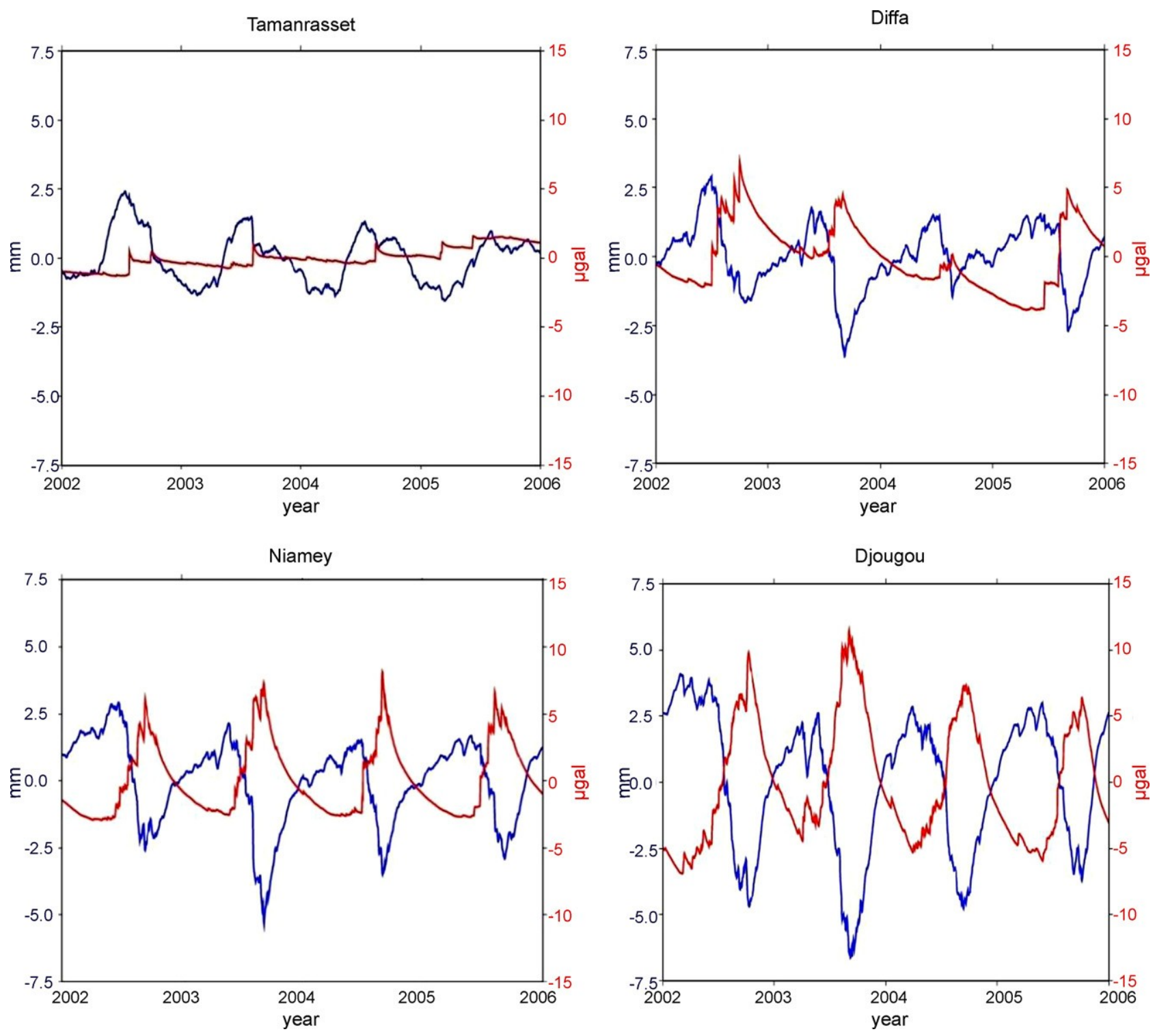

Fig. 4. Gravity changes (in $\square$ Gal) and vertical displacements (in $\mathrm{mm}$ ) due to the global hydrological load (soil moisture content) (GLDAS model) for the absolute gravity stations. (For interpretation of the references to color in this figure legend, the reader is referred to the web version of the article.)

sites are already equipped with geodetic GPS receivers: Niamey, Djougou in the framework of the AMMA program (see Bock et al., 2008), and Tamanrasset (CRAAG, Algeria). The location of the existing GPS permanent stations in West Africa is indicated in Fig. 5.

We propose to install the same equipment at the station of Diffa (Niger). The precision of the GPS receivers will allow to detect the crustal deformation induced by the surface loads (atmosphere, ocean and continental hydrology) reaching several $\mathrm{mm}$ for the vertical component as far as the hydrology loading is concerned (cf. Fig. 4).

Recently several studies have shown that GPS ground observations of the hydrological signal (Bevis et al., 2005) can be compared to GRACE data and used as a validation method (Davis et al., 2004). For a specific region undergoing a hydrological loading, de Linage et al. (2006, 2007) computed a characteristic mean ratio linking ground vertical motion to ground gravity change. This ratio can also be used to link satellite gravity to ground gravity, as an alternative to the spherical harmonic-based approach using load Love numbers (Neumeyer et al., 2006); we will use these relations in our validation experiment of the GRACE data based on ground gravity and GPS.

\subsection{Actions planned in hydrology and hydrogeophysics}

The Djougou and the Niamey sites are the mesoscale sites of the ongoing international AMMA-CATCH observatory (2003-2010) (http://ltheln21.hmg.inpg.fr/catch/). The Diffa site is located in the Lake Chad basin. Since it is at the northern edge of the monsoon area, it amplifies the variability of the monsoon. A description of these sites and of the studies planned there is provided below.

In the middle of a large sedimentary basin $\left(\begin{array}{lll}2.5 & \mathrm{Mkm} \quad{ }^{2}\end{array}\right)$, the Lake Chad is an endoreic shallow freshwater lake, only a few meter deep and therefore sensitive to climatic changes (Lemoalle, 2004), which is topping the Quaternary upper aquifer of the Chad lake basin. Due to the large scale of the basin it cannot be covered by conventional hydrological observatories. Thus satellite gravity data provide a unique opportunity to constrain the large scale and long-term evolution of the freshwater resources at the basin scale. This basin has 


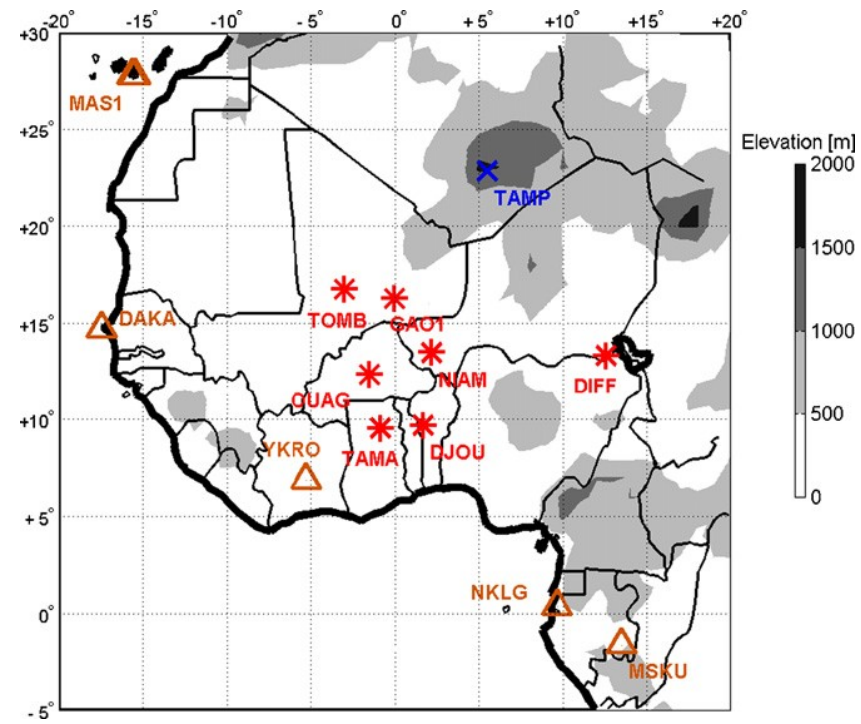

Fig. 5. Location of the GPS permanent stations in West Africa: in red the AMMAGHYRAF stations (Tombouctou, Gao, Ouagadougou, Tamale, Niamey, Djougou and Diffa), in blue the CRAAG station in Tamanrasset and in brown the nearby IGS stations. (For interpretation of the references to color in this figure legend, the reader is referred to the web version of the article.)

been explored by hydrologists since the 1950s. Since the 1990s, it has been subjected to numerous modelling efforts for groundwater and for surface water.

Two main challenges arise in the water budget of the basin: the first arises from the memory of a few thousands years of the aquifer (Leblanc et al., 2007), and the second one from the surface water inputs, particularly from the rivers and from the lake. Monitoring of the seasonal changes of surface water and groundwater performed since 2004 in the Niger part of the basin (ongoing surveys by local authorities) will help to constrain the distribution of water mass in the representative region of the Sahara-Sahel transition (Diffa, $300 \mathrm{~mm} /$ year). Immediately South of Diffa, the Komadougou river shows large seasonal variations and will be used as a key area to test the recharge of the aquifer by superficial rivers. To the North of Diffa, the Kadzell area is subject to very little recharge and its piezometric surface does not present any seasonal signal (Leduc et al., 2000). This best known area of the lake Chad Basin will be used as a feature of the desert area of the basin, which is devoid of any permanent water surface. This is the place where we will regularly measure absolute gravity with a A10 meter.

Within the framework of this project, a densification of the current monitoring network will make possible a decomposition of the gravimetric signal. Surface waters will be computed with the TMHB code (Coe and Foley, 2001) which will be built and calibrated. More local studies are proposed immediately near the location of the absolute gravimeter in order to assess the infiltration of water from the Komadougou river, the porosity (MRS) and water content of the sedimentary level surrounding the gravimeter (direct sampling of the sediment layer by drilling with a motored auger). So this site will both provide to the GHYRAF project the near northern limit of the monsoon domain, and introduce constraints from satellite and surface gravimetry to the water budget of the Chad quaternary aquifer. An additional constraint to the Lake Chad height is also provided by satellite radar altimetry as shown by Coe and Birkett (2004).

The Wankama Sahelian site is in the $1{ }^{\circ} \times 1^{\circ}$ mesoscale site close to Niamey (Niger) and the Soudanian site of Nalohou close to Djougou is part of the upper Ouémé catchment in Benin $\left(14,600 \mathrm{~km}^{2}\right)$, with average yearly rainfall of $1200 \mathrm{~mm}$. The water cycle observations have started in 2000 . One of the goals is to doc- ument processes involved in the surface redistribution of water (runoff, infiltration, evapotranspiration) and to quantify the different contributions to the surface water budget (Varado et al., 2006). Observation of the continental water cycle is based on a multi-scale (spatial and temporal) approach (Le Lay and Galle, 2005).

Local scale observations are dedicated to elementary processes studies. Detailed measurements of the water cycle components are performed on three transects (Kamagaté et al., 2007). In Niger, intensive observations are undertaken on elementary watersheds. These sites include soil water monitoring stations, piezometers, runoff on small gullies, vegetation monitoring and fluxes stations. These data, associated to knowledge of processes captured at local scale (see for example Massuel et al., 2006), are used in a hydrologic modelling framework to test and validate water cycle processes, characterize the water cycle compartments and quantify the water balance components, at intra-seasonal to inter-annual time scales.

One main interest of the Niamey site is that, in addition to seasonal changes in water storage in response to monsoonal rainfalls, a long-term rise in the water table dating back to the 1960s was shown to occur in response to land cover changes that promote infiltration of rainwaters (Leduc et al., 2001; Séguis et al., 2004). The observed rise in the water table is about $0.2 \mathrm{~m} /$ year and represents an increase in recharge of one order of magnitude for the past five decades (Favreau et al., 2009), with a present recharge rate of $\sim 25 \mathrm{~mm} /$ year. This water table rise is assumed to occur at the scale of the whole sedimentary aquifer (Continental Terminal, $150000 \mathrm{~km}^{2}$ ) so that the signal should be easily recorded by GRACE, as demonstrated by recent studies (e.g. Syed et al., 2005; Han et al., 2005; Yeh et al., 2006).

In Benin, the bedrock is metamorphic and groundwater is mainly located in the weathered layers (regolith) above. Groundwater is the main source of domestic water for the rural population. Piezometric levels are more or less parallel to the topography. There is not one regional aquifer but many hill slope aquifers with similar behaviors where a yearly recharge occurs during the rainy season. The water table peak is reached in August-September (2-m depth); then the level decreases until May (10-m depth). This level change could correspond to a $0.4 \mathrm{~m}$ pure water thickness (assuming for example a $5 \%$ porosity), to which should be added the $0.25 \mathrm{~m}$ thickness which is estimated to be present in the unsaturated soil. Despite the small porosity estimated in the zone (a few per cent), this leads to a large predicted effect in gravity which will be easily detected both by the superconducting gravimeter in Djougou and by the repeated absolute gravity measurements there.

One objective of the project is to better constrain the regional modelling of the hydrologic behaviour of this region by adding external information given by gravity measurements. For the Benin site, hydrological modelling has been developed according to the processes identified at the local scale (Le Lay et al., 2008). In this model, all the components of the water budget (evapotranspiration, subsurface flow, recharge of the groundwater, stream flow) are calculated. The model is calibrated (and validated) against stream flow discharge because it is the only integrated component known at the watershed scale, which can be easily measured. To fill the gap between the small watershed $\left(10 \mathrm{~km}{ }^{2}\right)$ and the regional scale, one needs a dense network of instruments but, practically, there are only about forty of hand-drilled wells monitored on the whole Upper Ouémé catchment. A satellite evaluation of the groundwater recharge would be of great help in our effort to fill the gap between the small watershed scale and the regional scale and thus to close the water budget at the mesoscale. Conversely, the results of the regional hydrologic modelling can be used as a validation tool for the satellite data.

A second objective is more local and consists in achieving a good evaluation of the underground storage to explain the gravimetric fluctuations. At present, only the hydraulic conductivity 
Table 2

Results from the first repetition of absolute gravity measurements before and after the 2008 monsoon.

\begin{tabular}{llll}
\hline Station & Dates & Gravity (in $\square$ Gal) & Difference (in $\square$ Gal) \\
\hline Wankama & July 17, 2008 & $978250602.7 \pm 2.0$ & \\
Wankama & September 4, 2008 & $978250611.4 \pm 1.7$ & $8.7 \pm 2.6$ \\
Nalohou & July 9, 2008 & $978033590.4 \pm 1.3$ & \\
Nalohou & September 30, 2008 & $978033603.6 \pm 1.7$ & $13.2 \pm 2.1$ \\
Bagara & July 13, 2008 & $978216783.8 \pm 1.7$ & \\
Bagara & October 10, 2008 & $978216784.7 \pm 1.5$ & $0.9 \pm 2.3$ \\
\hline
\end{tabular}

of the aquifer has been more or less known by slug tests. propose to characterize precisely the aquifer (porosity and conductivity) by an inter-comparison of two methods: (1) classical pumping test and (2) subsurface geophysical characterization. The objective of this geophysical characterization is to get a more integrated measurement of the aquifer properties than those obtained with pumping tests. Subsurface geophysics can be used to better constrain changes in water storage. In the selected sites, MRS (Magnetic Resonance Sounding) surveys will be used to estimate changes occurring in groundwater volume during the rainy season by estimating the vertical distribution of MRS water content. For two of the selected sites (Niamey and Djougou), preliminary investigations in 2005 and 2006 showed that this methodology is well adapted for aquifers in crystalline context in India (Descloitres et al., 2008) or in West Africa (Vouillamoz et al., 2005; Descloitres et al., 2007). In Niger for sedimentary context, MRS has been successfully applied to aquifer characterization (Vouillamoz et al., 2008).

\subsection{Ground truth for satellite-derived gravity observations}

A major effort to determine the temporal changes in the Earth's gravity field was initiated with CHAMP and GRACE missions. analysis of the first GRACE data after correction for the tides (solid Earth + oceans), oceanic response to air pressure, 3D mass redistribution in the atmosphere and polar motion, has revealed a clear annual signal connected to continental hydrology (soil moisture + snow coverage + groundwater) (Tapley et al., 2004; Wahr et al., 2004; Ramillien et al., 2004; Schmidt et al., 2006).

However, the hydrology models exhibit a large variability in many regions. In particular, there is a higher variability especially in the equatorial band in Africa where the standard deviation among models reaches $2 \square$ Gal (Andersen et al., 2005). GRACE data do generally agree with hydrological models but it is almost impossible to conclude whether the discrepancies arise from the model deficiencies or from errors in the GRACE solutions. Also, the different resolution of GRACE data (say $400 \mathrm{~km}$ ) and global hydrology models (say $100 \mathrm{~km}$ ) leads to estimate the water storage variation in different spectral bands. Therefore the need for independent data allowing a real validation is obvious.

One possible reference signal to be used for validating the satellite gravity observations is indeed the seasonal signal from continental hydrology. It reaches several $\square$ Gal in regions like Europe and can even be as large as $20 \square$ Gal in specific points in Africa like the Djougou site in Benin (cf. Fig. 4). Only a few comparisons of satellite-derived gravity data with ground data are available until now. Methodological investigations (Crossley and Hinderer, 2002; Crossley et al., 2003; Hinderer et al., 2006a) have shown the benefit of using a regional network of superconducting gravimeters for validation purpose. For instance, the analysis of the European GGP network has demonstrated, with the help of empirical orthogonal functions, the presence of a coherent seasonal signal in surface gravity which is highly correlated to continental hydrology. A preliminary comparison between SG data, hydrology model predictions and GRACE data was achieved (Crossley et al., 2004, 2005; Hinderer et al., 2006b) showing a fair agreement.

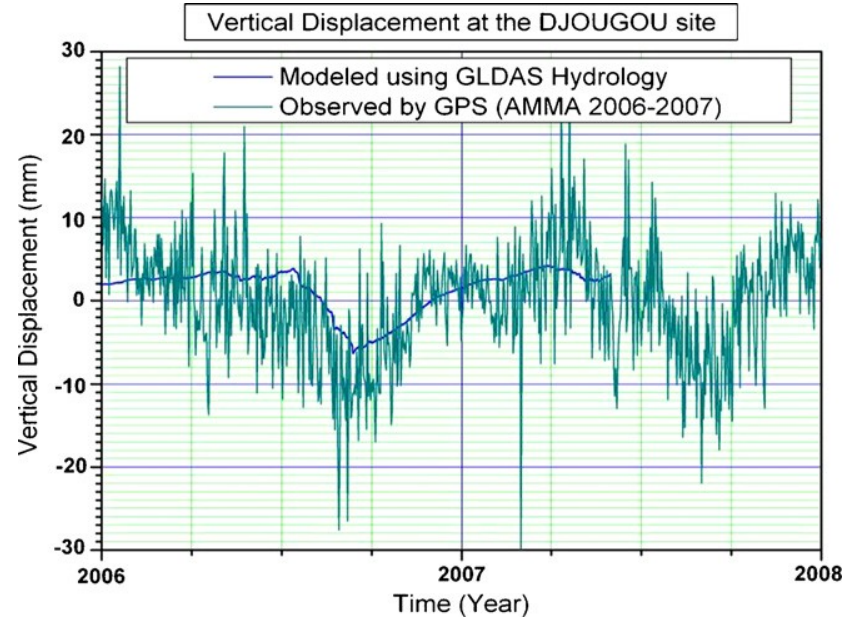

Fig. 6. Preliminary results concerning the vertical displacement at Djougou (Benin); in green the daily observed GPS data and in blue the daily modelled contribution from GLDAS. (For interpretation of the references to color in this figure legend, the reader is referred to the web version of the article.)

is worth to mention here that the precision of our ground absolute gravity measurements (2 $\square \mathrm{Gal}$ according to Table 2 ) as well as the accuracy of the GRACE satellite data which depends on latitude and filtering strategy (Wahr et al., 2006; Lemoine et al., 2007) (for example, at the equator, the error on Gaussian-averaged mass values with a 750-km smoothing radius is $1 \square$ Gal while the error on non-averaged constrained estimates at $400-\mathrm{km}$ resolution reaches $2.5 \square \mathrm{Gal}$ ) should allow to discriminate different hydrology models at different spatial scales (see Andersen et al., 2005 for a discussion of the discrepancies in these models).

All these studies involving SGs at the ground are relatively limited by the quite small amplitude of the seasonal gravity changes due to hydrology in Europe (Boy and Hinderer, 2006) and often by the lack of knowledge of the local hydrologic environment. There is presently no GGP station installed in a zone with strong hydrological signal or, on the contrary, in a zone with no signal at all (appropriate for the 'null test'). This is why we plan to install in the framework of GHYRAF a new SG station in West Africa with such a large hydrological signal and where the water storage variations are well constrained locally by hydrogeological monitoring.

\section{First results}

The GHYRAF project started effectively in March 2008 by a first reconnaissance campaign in Niger and Benin where we identified the three AG sites in Wankama, Bagara and Naholou in close connection with the hydrologists working on these sites.

We also found the place for installing the new permanent GPS receiver in Diffa close to a building of the Service de l'Hydraulique. The work to assemble pillars and the buildings for the AG stations was done in May and June 2008, as well as the pillar for the GPS antenna. Therefore we could indeed perform the first AG measurements in early July 2008 without missing the initial rainfall of the 2008 monsoon. Similarly a second campaign occurred in September 2008 in order to catch the highest possible hydrology signal due to the monsoon.

One goal of the GHYRAF project is to detect from the GPS regional network the signature in vertical displacement of the hydrological load caused by the monsoon. Therefore we did a first test using the 2006-2007 GPS data for Djougou where the largest effect is predicted (see Fig. 4). Fig. 6 shows the results of the processing where we superimposed the predicted displacement from the GLDAS hydrology load. Despite the high frequency content of the GPS solu- 

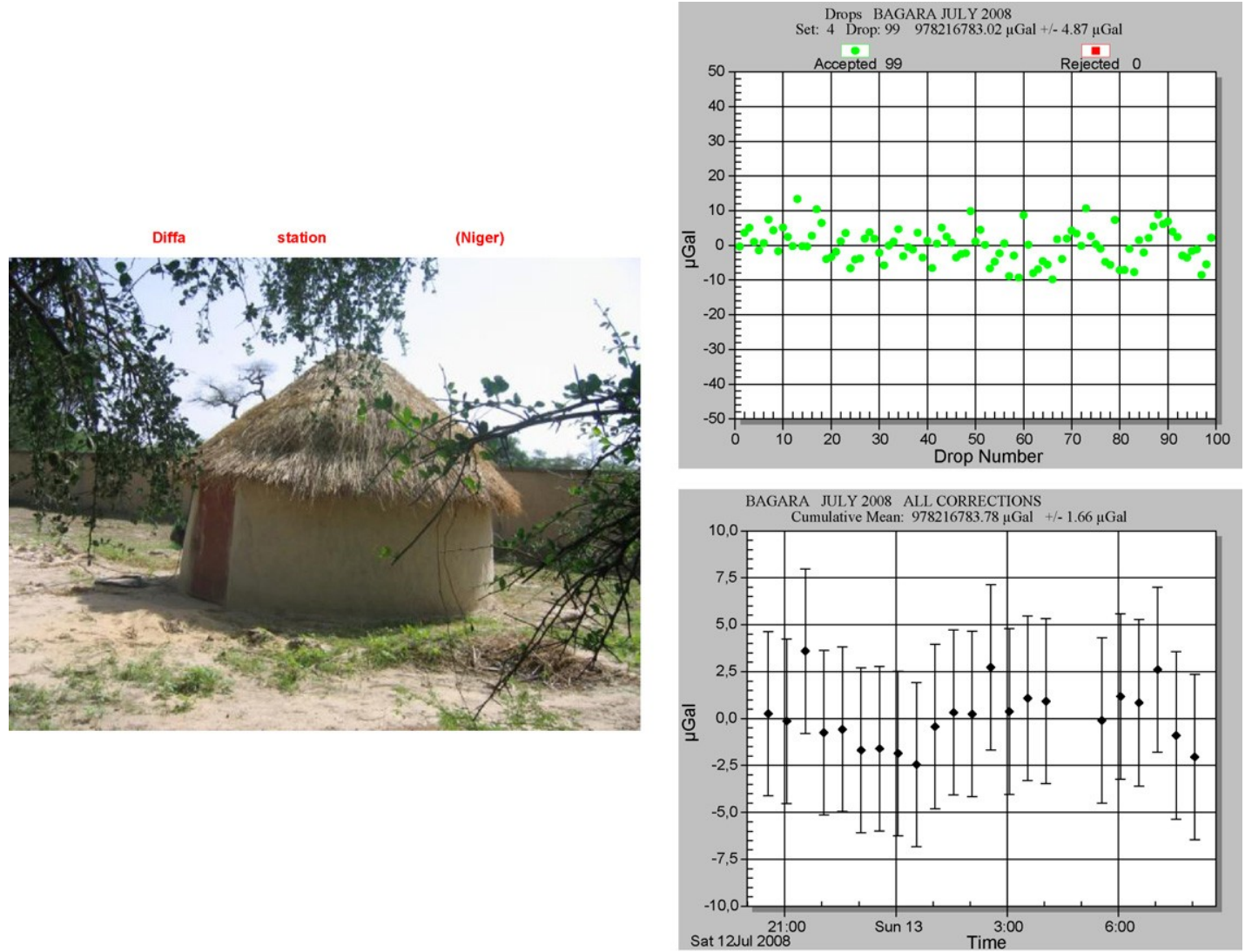

Fig. 7. Absolute gravity measurements at Bagara station (near Diffa, Niger); the upper right plot shows the drop by drop scatter and the lower right plot the scatter in the set values (one set every 30 mins).

tion (maybe due to tropospheric humidity and/or the uncorrected effect of the atmospheric pressure on the signal), it is very obvious that there is a signal of about $10 \mathrm{~mm}$ strongly related to the monsoon in the data which is in close agreement with the model. Therefore we hope in the future in the framework of the project to further assemble longer data sets in more location in West Africa to better investigate the monsoon hydrology load.

Since we did not yet identify the right place to set up the 'null test' in the Sahara (the first survey is planned in January 2009 around Tamanrasset), we report here only preliminary results coming from the first repetition of absolute gravity measurements on the station Wankama (Niamey), Nalohou (Djougou) and Bagara (Diffa); these results are summarised in Table 2.

Fig. 7 shows the AG results for the station of Bagara constructed using a local traditional design. One can see that the drop scatter is rather good below $5 \square$ Gal which leads to a small uncertainty of less than $2 \square \mathrm{gal}$ on the final gravity value; as usually, this final value is corrected for solid and oceanic tides, polar motion, air pressure and given on a fixed geodetic mark to avoid any effect linked to height changes in the mounting of the instrument. We tried to measure gravity at dates before and after the monsoon to catch as much as possible the effects due to the rain. From Table 2 it appears that we have a clear gravity increase at the Sahelian station of Wankama of $+8.7 \pm 2.6 \square \mathrm{Gal}$ and $+13.2 \pm 2.1 \square \mathrm{Gal}$ at the Nalohou station where occurs the highest rainfall. On the contrary, the station of Bagara located in the Chad basin exhibits almost no gravity change: $+0.9 \pm 2.3 \square$ Gal. The changes in Wankama and Nalohou are close to predictions given by the hydrologists working on this region from their knowledge of water table heights changes and water content in the vadose zone. A more precise modelling with the 2008 data is underway. It might be surprising that there is no gravity change at Bagara but the local and regional hydrology con- text is clearly different with a strong phase shift in the maximum of the water content in the ground as seen in previous years in piezometric and soil moisture measurements (Gaultier, 2004).

\section{Conclusion}

We have presented the GHYRAF (Gravity and Hydrology in Africa) project by detailing the specific actions in gravimetry, GPS and hydrology planned on four sites in the Sahara and West Africa. This project started in spring 2008 and will last 3 years (2008-2010). The initial phase has already led to install a new GPS permanent receiver in Diffa (Niger) which is operational since July 2008 and which complements the existing AMMA network in West Africa. A first analysis of the GPS vertical motion of the Djougou site shows that the seasonal hydrology signal predicted by global models like GLDAS or LaDWorld is indeed visible in the data despite the presence of high frequency perturbations. A first absolute gravity campaign with FG5\#206 was performed in early July at the beginning of the monsoon rainfalls at Wankama (near Niamey) and Bagara (near Diffa) in Niger, as well as at Nalohou (near Djougou) in Benin. The quality of the measurements is excellent despite several problems (lack of electrical power, weather, logistics) demonstrating the feasibility of the project. A fourth site to be representative of the desert conditions with almost no hydrological signal is planned near Tamanrasset (Algeria) and will selected in early 2009. The first repetition of the absolute gravity measurements was done in September-October 2008 leading to gravity increases in Wankama and Djougou of 9 and $13 \square \mathrm{Gal}$ respectively related to the increase in the soil water content and water table rise during the monsoon. More work is now required to link these new results to the hydrology data available both for the unsaturated zone and for groundwater in these two sites. 


\section{Acknowledgments}

This project is funded by the French Agence Nationale de la Recherche (ANR) for 3 years (2008-2010). We also acknowledge the financial support of the Institut National des Sciences de l'Univers (INSU) in the purchase of the superconducting gravimeter. would like to point out the strong logistic and manpower support found in Niger and Benin thanks to the Institut de Recherche pour le Développment (IRD). Finally, assistance of local water authorities in Niger and Benin is also warmly acknowledged. Among them we kindly thank the Direction Régionale de l'Hydraulique in Diffa for its help in the GPS installation and maintenance.

\section{References}

Andersen, O., Hinderer, J., Lemoine, F., 2005. Seasonal gravity field variations from GRACE and hydrological models. In: Jekeli, Bastos, Fernandes (Eds.), Gravity, Geoid and Space Missions. IAG Symposia, vol. 129. Springer Verlag, pp. 316-321.

Bates, B.C., Kundzewicz, Z.W., Wu, S., Palutikof, J.P.(Eds.), 2008. Climate Change and Water. Tech. Paper of the Intergovernmental Panel on Climate Change, IPCC Secretariat, Geneva, $210 \mathrm{pp}$.

Bevis, M., Alsdorf, D., Kendrick, E., Fortes, L., Forsberg, B., Smalley, R., Becker, J., 2005. Seasonal fluctuations in the mass of the Amazon river system and Earth's elastic response. Geophys. Res. Lett. 32, L16308, doi:10.1029/2005GL023491.

Bock, O., Bouin, M.N., Doerflinger, E., Collard, P., Masson, F., Meynadier, R., Nahmani, S., Koité, M., Gaptia Lawan Balawan, K., Didé, F., Ouedraogo, D., Pokperlaar, S., Ngamini, J.-B., Lafore, J.P., Janicot, S., Guichard, F., Nuret, M., 2008. The West African Monsoon observed with ground-based GPS receivers during AMMA. Geophys. Res. 113, D21105, doi:10.1029/2008JD010327.

Boy, J.-P., Hinderer, J., 2006. Study of the seasonal gravity signal in superconducting gravimeter data. J. Geodyn. 41, 253-258.

Coe, M.T., Foley, J.A., 2001. Human and natural impacts on the water ressources of the Lake Chad basin. J. Geophys. Res. (Atmos.) 106 (D4), 3349-3356.

Coe, M.T., Birkett, C.M., 2004. Calculation of river discharge and prediction of lake height from satellite radar altimetry: example for the Lake Chad basin. Water Resour. Res. 40, W10205, doi:10.1029/2003WR002543.

Crossley, D., Hinderer, J., Casula, G., Francis, O., Hsu, H.-T., Imanishi, Y., Jentzsch, G., Kaarianen, J., Merriam, J., Meurers, B., Neumeyer, J., Richter, B., Shibuya, K., Sato, T., T. van Dam, 1999. Network of superconducting gravimeters benefits a number of disciplines. EOS, Transactions, AGU, 80(11), 121, 125-126.

Crossley, D., Hinderer, J., 2002. GGP ground truth for satellite gravity missions. Bull. Inf. Marées Terr. 136, 10735-10742.

Crossley, D., Hinderer, J., Llubes, M., Florsch, N., 2003. The potential of ground gravity measurements to validate GRACE data. Adv. Geosci. 1, 1-7.

Crossley, D., Hinderer, J., Boy, J.-P., 2004. Regional gravity variations in Europe from superconducting gravimeters. J. Geodyn. 38, 325-342.

Crossley, D., Hinderer, J., Boy, J.-P., 2005. Time variation of the European gravity field from superconducting gravimeters. Geophys. J. Int. 161, 257-264.

Davis, J., Elosegui, P., Mitrovica, J., Tamisea, M., 2004. Climate-driven deformation of the solid Earth from GRACE and GPS. Geophys. Res. Lett. 31, L24605, doi:10.1029/2004GL021435.

Descloitres, M., Séguis, L., Wubda, M., \& Legchenko, A., 2007. Discrimination of rocks with different hydrodynamic properties using MRS, EM and resistivity methods. Paper B33, 13th European Meeting on Environmental and Engineering Geophysics "Near Surface 2007", Istambul, Turkey, September 3-5.

Descloitres, M., Ruiz, L., Sekhar, M., Legchenko, A., Braun, J.J.,Mohan Kumar, M.S., Subramanian, S., 2008. Characterization of seasonal local recharge using Electrical Resistivity Tomography and Magnetic Resonance Sounding. Hydrol. Process. 22, 384-394.

de Linage, C., Hinderer, J., Boy, J.-P., 2006. A search on the gravity/height ratio induced by surface loading; theoretical investigation and numerical applications. Bull. Inf. Marées Terr. 143, 11451-11460.

de Linage, C., Hinderer, J., Rogister, Y., 2007. A search for the ratio between gravity variation and vertical displacement due to a surface load. Geophys. J.Int. 171, 986-994.

Favreau, G., Cappelaere, B., Massuel, S., Leblanc, M., Boucher, M., Boulain, N., Leduc, C., 2009. Land clearing, climate variability, and water resources increase in semiarid southwest Niger: a review. Water Resour. Res. 45, W00A16, doi:10.1029/2007WR006785.

Gaultier, G., 2004. Recharge et paléorecharge d'une nappe libre en milieu Sahélien (Niger oriental): approche géochimique et hydrodynamique, Ph.D. Thesis, Université de Paris-XI, Orsay, France.

Gehman, C.L., Harry, D.L., Sanford, W.E., Stednick, J.D., Beckman, N.A., 2009. Estimating specific yield and storage change in an unconfined aquifer using temporal gravity surveys. Water Resour. Res. 45, W00D21, doi:10.1029/2007WR006096.

Han, S.-C., Shum, C.K., Jekeli, C., Alsdorf, D., 2005. Improved estimation of terrestrial water storage changes from GRACE. Geophys. Res. Lett. 32, L07302, doi:10.1029/2005GL022382.

Hinderer, J., Crossley, D., 2000. Time variations in gravity and inferences on the Earth's structure and dynamics. Surv. Geophys. 21, 1-45.
Hinderer, J., Crossley, D., 2004. Scientific achievements from the first (1997-2003) of the Global Geodynamics Project using a worldwide network of superconducting gravimeters. J. Geodyn. 38, 237-262.

Hinderer, J., de Linage, C., Boy, J.-P., 2006a. How to validate satellite-derived gravity observations with gravimeters at the ground? Bull. Inf. Marées Terr. 142, 11433-11441.

Hinderer, J., Andersen, O., Lemoine, F., Crossley, D., Boy, J.-P., 2006b. Seasonal changes of the Earth's gravity field from GRACE: a comparison with ground measurements from superconducting gravimeters and with hydrology model predictions. J. Geodyn. 41, 59-68.

Jacob, T., Bayer, R., Chery, J., Jourde, H., Le Moigne, N., Boy, J.P.,Hinderer, J., Luck B., Brunet, P., 2008. Absolute gravity monitoring of water storage variation in a karst aquifer on the Larzac plateau (Southern France). J. Hydrol. 359 (1-2), 105-117, doi:10.1016/j.jhydrol.2008.06.020.

Kamagaté, B., Séguis, L., Favreau, G., Seidel, J.L.,Descloitres, M., Affaton, P., 2007. Hydrological processes and water balance of a tropical crystalline bedrock catchment in Benin (Donga, upper Ouémé River). C.R. Geosci. 339, 418-429.

Lebel, T., Redelsperger, J.-L., Thorncroft, C., 2003a. African Monsoon Multidisciplinary analysis (AMMA) project. Gewex Newsl. 13 (4), 8-9.

Lebel, T., Diedhiou, A., Laurent, H., 2003b. Seasonal cycle and interannual variability of the Sahelian rainfall at hydrological scales. J.Geophys. Res. 108 (D8), 8389, doi:10.1029/2001JD001580.

Leblanc, M., Favreau, G., Tweed, S., Leduc, C., Razack, M., Mofor, L., 2007. Remote sensing for groundwater modelling in large semiarid areas: Lake Chad Basin, Africa. Hydrogeol. J. 15, 97-100.

Leduc, C., Sabljak, S., Taupin, J.D., Marlin, C., Favreau G, 2000. Recharge of the Quaternary water table in the northwestern Lake Chad basin (southeastern Niger) estimated from isotopes. C.R. Acad. Sci. Paris Ila 330 (5), 355-361.

Leduc, C., Favreau, G., Schroeter, P., 2001. Long-term rise in a Sahelian water-table: the Continental Terminal in South-West Niger. J. Hydrol. 243, 43-54.

Le Lay, M., Galle, S., 2005. How changing rainfall regimes may affect the water balance. A modelling approach in West Africa in «Regional hydrological impacts of climatic changes-Hydroclimatic variability» IAHS Publ. no. 296, pp. 203-210.

Le Lay, M., Saulnier, G.-M., Galle, S., Séguis, L., Métadier, M., Peugeot, C., 2008. Model representation of the Sudanian hydrological processes. Application on the Donga catchment (Benin). J. Hydrol., http://dx.doi.org/10.1016/j.jhydrol.2008.09.006.

Lemoalle, J.,2004. Lake Chad: a changing environment. In: Nihoul, J.C.J.Zavialov, P.O., Micklin, P.P. (Eds.), Dying and Dead Seas: Climatic versus Anthropic Causes. Proceedings of the NATO Advanced Workshop on Dying and Dead Seas, May 2003, Liege, Belgium. NATO Science Series VI, Earth and environmental sciences, vol. 36. Kluwer Academic Publishers, Dordrecht, The Netherlands, pp. 321-329.

Lemoine, J.-M., Bruinsma, S., Loyer, S., Biancale, R., Marty, J.-C., Perosanz, F., Balmino, G., 2007. Temporal gravity field models inferred from GRACE data. Adv. Space Res. 39, 1620-1629.

L'Hote et Mahé, 1996. Afrique centrale et de l'Ouest: carte des precipitation moyennes annuelles (période 1951-1989)—IRD (ORSTOM), Bondy, France.

Massuel, S., Favreau, G., Descloitres, M., Le Troquer, Y., Albouy, Y., Cappelaere, B., 2006. Deep infiltration through a sandy alluvial fan in semiarid Niger inferred from electrical conductivity survey, vadose zone chemistry and hydrological modelling. CATENA 67 (2), 105-118.

Milly, P.C.D., Shmakin, A.B., 2002. Global modeling of land water and energy balances. Part I: The land dynamics (LaD) model. J. Hydrometeorol. 3 (3), 283-299.

Naujoks, M., Weise, A., Kroner, C., Jahr, T., 2008. Detection of small hydrological variations in gravity by repeated observations with relative gravimeters. J. Geodesy 82, 543-553.

Neumeyer, J., Barthelmes, F., Dierks, O., Flechtner, F., Harnisch, M., Harnisch, G., Hinderer, J., Imanishi, Y., Kroner, C., Meurers, B., Petrovic, S., Reigber, C., Schmidt, R., Schwintzer, P., Sun, H.-P., Virtanen, H., 2006. Combination of temporal gravity variations resulting from Superconducting Gravimeter (SG) recordings, GRACE satellite observations and global hydrology models. J. Geodesy, doi:10.1007/s00190-005-0014-8

Niebauer, T., Sasagawa, G., Faller, J., Hilt, R., Klopping, F., 1995. A new generation of absolute gravimeters. Metrologia 32, 159-180.

Pool, D.R., Eychaner, J.H., 1995. Measurements of aquifer-storage change and specific yield using gravity surveys. Ground Water 33 (3), 425-432, doi:10.1111/j.17456584.1995.tb00299.x.

Ramillien, G., Cazenave, A., Brunau, O., 2004. Global time variations of hydrological signals from GRACE satellite gravimetry. Geophys. J. Int. 158, 813-826.

Redelsperger, J.L., Thorncroft, C.D., Diedhiou, A., Lebel, T., Parker, D.J., Polcher, J., 2006 African Monsoon Multidisciplinary Analysis: an international research project and field campaign. Bull. Am. Meteorol. Soc. 87, 1739-1746.

Rodell, M., Houser, P.R., Jambor, U., Gottschalck, J., Mitchell, K., Meng, C.-J., Arsenault, K., Cosgrove, B., Radakovich, J., Bosilovich, M., Entin, J.K., Walker, J.P., Lohmann, D., Toll, D., 2004. The Global Land Data Assimilation System. Bull. Am. Meteor. Soc. 85 (3), 381-394.

Schmidt, R., Schwintzer, P., Flechtner, F., Reigber, C., Güntner, A., Döll, P., Ramillien, G., Cazenave, A., Petrovic, S., Jochmann, H., Wünsch, J., 2006. GRACE observations of changes in continental water storage. Global Planet. Changes 50, 112-126, doi:10.1016/j.gloplacha.2004.11.018

Séguis, L., Cappelaere, B., Milési, G., Peugeot, C., Massuel, S., Favreau, G., 2004. Simulated impacts of climate change and land-clearing on runoff from a small Sahelian catchment. Hydrol. Process. 18, 3401-3413, doi:10.1002/hyp.1503.

Syed, T., Famiglietti, J., Chen, J., Rodell, M., Seneviratne, S., Viterbo, P., Wilson, C., 2005. Total basin discharge for the Amazon and Mississippi river basins from GRACE and a land-atmosphere water balance. Geophys. Res. Lett. 32, L24404 doi:10.1029/2005GL024851. 
Tapley, B., Bettadpur, S., Ries, J., Thompson, P., Watkins, M., 2004. Grace measurements of mass variability in the Earth system. Science 305, 503-505 doi:10.1126/science.1099192.

Van Camp, M., Vanclooster, M., Crommen, O., Petermans, T., Verbeeck, K., Meurers, B., van Dam, T., Dassargues, A., 2006. Hydrogeological investigations at the Membach station, Belgium and application to correct long periodic gravity variations. J. Geophys. Res. 111, B10403, doi:10.1029/2006JB004405.

Varado, N., Braud, I., Galle, S., Le Lay, M., Séguis, L., Kamagate, B., Depraetere, C., 2006. Multi-criteria assessment of the Representative Elementary Watershed approach on the Donga catchment (Benin) using a downward approach of mode complexity. Hydrol. Earth Syst. Sci. 10, 427-442.

Vouillamoz, J.M., Descloitres, M., Toe, G., Legchenko, A., 2005. Characterization of crystalline basement aquifers with MRS: comparison with boreholes and pumping tests data in Burkina. Near Surf. Geophys. 3, 107-111.
Vouillamoz, J.M., Favreau, G., Massuel, S., Boucher, M., Nazoumou, Y., Legchenko, A., 2008. Contribution of magnetic resonance sounding to aquifer characterization and recharge estimate in semiarid Niger. J. Appl. Geophys. 64, 99-108.

Wahr, J., Swenson, S., Zlotnicki, V., Velicogna, I., 2004. Time-variable gravity from GRACE: first results. Geophys. Res. Lett. 31 (11), L11501, doi:10.1029/2004GL019779.

Wahr, J., Swenson, S., Velicogna, I., 2006. Accuracy of GRACE mass estimates. Geophys. Res. Lett. 33, L06401, doi:10.1029/2005GL025305

Yeh, P.J.-F., Swenson, S.C., Famiglietti, J.S., Rodell, M., 2006. Remote sensing of groundwater storage changes in Illinois using the Gravity Recovery and Climate Experiment (GRACE). Water Resour. Res. 42, W12203, doi:10.1029/2006WR005374. 